ISSN : 2550-0198

\title{
PEMBERDAYAAN USAHA MASYARAKAT MELALUI BRANDING PRODUK
}

\author{
Hendri Ali Ardi*, Siti Samsiah, Wahyi Busyro, Siti Hanifa Sandri, Misral, \\ Sri Rahmayanti. \\ Keuangan \& Perbankan, Fakultas Ekonomi dan Bisnis \\ Universitas Muhammadiyah Riau \\ *Email: hendrialiardi79@gmail.com
}

\begin{abstract}
Abstrak
Rendahnya kemampuan bersaing produk-produk UMKM kota Pekanbaru menjadi anomaly ditengah tingginya angka pertumbuhan usaha tersebut. Hal tersebut dimungkinkan karena ketidakmampuan UMKM dalam menciptakan jati diri untuk produkproduk mereka sehingga mudah teridentifikasi dan terdiferensiasi. Pengabdian kepada masyarakat ini bertujuan untuk mengatasi permasalahan tersebut diatas melalui perancangan produk, merek dan branding yang memiliki keunggulan kompetitif, selain memberikan pengetahuan dan wawasan akan arti penting branding produk.pengabdian dilakukan dengan pendekatan brainstorming dan SWOT sebagai teknik analisis,kegiatan pengabdian ini menghasilkan produk berupa sabun cuci dan mandi cair dengan thematic buah-buahan dan memakai merek SEEPRazes.
\end{abstract}

Kata kunci : produk, branding, brainstorming

\section{PENDAHULUAN}

Hasrat berwirausaha masyarakat dari waktu ke waktu menunjukkan trend positif. Hal tersebut tergambar pada data perkembangan UMKM kota Pekanbaru yang hingga saat ini telah berjumlah sebanyak 67.728 unit usaha, jumlah terbanyak dibandingkan Kota/Kabupaten lain di Propinsi Riau.

Terbanyak, belum tentu terbaik. Ungkapan tersebut rasanya pas untuk menggambarkan kondisi UMKM kota Pekanbaru. Dengan jumlah puluhan ribu usaha yang terdiri dari berbagai tipe bisnis, tidak satu usahapun yang mampu memberikan warna signifikan atas perkembangan perekonomian daerah.
Bandingkan dengan Kota Bandung dengan 5.198 unit usaha. UMKM-nya mampu memberikan kontribusi ekonomi untuk propinsi Jawa Barat rata-rata $11,6 \%$. Tidak hanya itu, melalui UMKM-nya, Kota Bandung dapat membranding dirinya sebagai salah satu pusat kuliner, fashion, kerajinan tangan, jasa, dan perdagangan terkemuka di Indonesia. Hal tersebut menempatkan kota Bandung sebagai salah satu destinasi wisata terfavorit dan ternama di Indonesia maupun mancanegara.

Secara prinsip, keseluruhan produk yang terdapat di kota Bandung, tersedia atau bisa diproduksi di kota Pekanbaru. Namun tetap tidak mampu mewarnai kancah bisnis kota Pekanbaru. 


\section{ISSN : 2550-0198}

Dalam rangka mempertahankan kelangsungan hidup organisasi, tumbuh dan bersaing dalam iklim persaingan saat ini, pengusaha UKMkota Pekanbaru seyogianya mempelajari kondisi pasar dan mengimplementasikan strategi yang efektif. Menurut Anarnkaporn (2007) Salah satu dari semua alat untuk memenangkan persaingan UKMyang menempati urutan pertama adalah branding

\section{Urgensi Pengabdian}

Kegiatan pengabdian dengan tema "pemberdayaan usaha masyarakat melalui branding produk" menjadi sesuatu yang penting bagi para pelaku usaha, terutama wirausaha baru.

Menjadi penting karena malalui branding, produk akan teridentifikasi dan terdiferensiasi dengan baik sehingga lebih mudah dikenali dan diingat oleh pembeli. Melalui branding produk, pelaku-pelaku usaha baru yang notabene berskala kecil mampu bersaing dengan pelakupelaku usaha menengah atau besar dalam memenuhi kebutuhan individu, organisasi dan masyarakat luas di pasaran secara sehat dan fair.

\section{Rasionalisasi Kegiatan}

Kegiatan pengabdian dilakukan melalui brainstorming.Brainstorming adalah proses berpikir lateral, mengajak setiap orang dating dengan ide-ide dan pemikiran yang terkesan gila dan tidak masuk akal pada awalnya. Namun, kemudian ide "gila" tersebut diubah atau diperbaiki menjadi ide-ide yang bermanfaat.

\section{Tujuan Kegiatan}

Dua hal yang ingin kami capai melalui Kegiatan pengabdian ini yaitu:

1. Pelaku-pelaku usaha memiliki pengetahuan dan wawasan tentang brand (merek) dan branding (cara mengkomunikasikan merek)

2. Rancangan produk, merek beserta branding untuk mencapai keunggulan kompetitif

\section{Rencana Pemecahan Masalah}

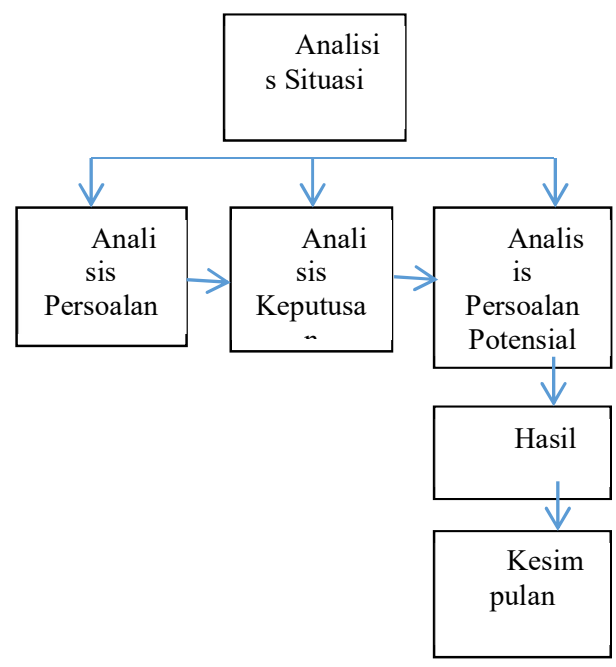

Gambar 1 Rencana Pemecahan Masalah

\section{Tinjauan Pustaka}

\section{Produk}

Produk didefinisikan sebagai segala sesuatu yang dapat ditawarkan ke pasar untuk mendapatkan perhatian, dibeli, dipergunakan, atau dikonsumsi dan apa yang dapat memuaskan keinginan atau kebutuhan (Thamrin dan Francis, 2016) 
Perencanaan produk harus memikirkan produk pada tiga tingkat sebagaimana tersaji pada gambar berikut:

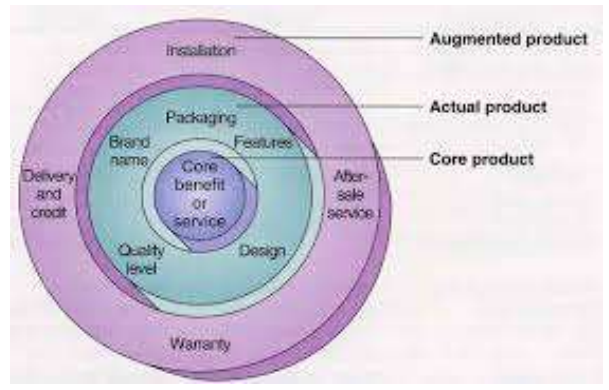

Gambar 2 Tingkatan Produk

\section{Merek}

Dalam buku Manajemen Pemasaran, Sofjan Assauri (2015) mendefinisikan merek sebagai nama, istilah, tanda atau lambang, dan kombinasi dari dua atau lebih unsur tersebut, yang dimaksudkan untuk mengidentifikasikan (barang atau jasa) dari seorang penjual atau kelompok penjual dan yang membedakannya dari produk saingan.

Memilih dan membuat merek yang tepat merupakan sebuah langkah penting, karena merek tersebut merupakan elemen penting dalam strategi pemasaran produk. Dalam memilih sebuah merek, terdapat lima hal penting yang perlu diperhatikan

Periksa terlebih dahulu bahwa merek yang dipilih telah memenuhi persyaratan hukum untuk pendaftaran

Lakukan penelusuran merek guna meyakinkan bahwa merek yang akan digunakan tersebut tidak identik atau mirip dengan merek-merek produk yang sudah ada dan terdaftar sebelumnya
Pastikan bahwa merek yang akan digunakan tersebut dapat dibaca, ditulis, dieja, dan diingat dengan mudah dan sesuai untuk semua media periklanan

Pastikan bahwa merek tersebut tidak memiliki konotasi yang tidak baik atau negative dalam bahasa di Negara yang bersangkutan ataupun di Negara-negara yang merupakan pasar potensial ekspor

Periksalah bahwa nama domain yang berkenaan bisa didaftarkan

Menurut Alma (2011) suatu merek yang dilancarkan oleh produsen merupakan suatu janji produsen yang sifatnya spesifik dan benefit yang ditawarkan kepada konsumen. Merek yang baik dan terkenal menjamin adanya tingkatan mutu atau kualitas. Kotler menyatakan ada enam arti dari merek yaitu:

1. Attributes, ada sesuatu atribut yang melekat pada suatu merek, misalnya barang mahal, mutu bagus, tahan lama, tidak luntur, dsb.

2. Benefit, kata atribut diartikan sebagai functional dan emotional benefit

3. Value barang mahal memiliki nilai tinggi bagi pengguna.

4. Menaikkan gengsi/prestige, kenyamanan,

dan keselamatan

5. Culture, ini masalah budaya, yang terkesan, terkenal, efisien, selalu membeli barang berkualitas tinggi

6. Personality, memperlihatkan atau memberi kesan kepribadian tertentu 


\section{ISSN : 2550-0198}

Para pelaku usaha mempunyai empat pilihan kalau berbicara tentang strategi merek.Pelaku-pelaku usaha dapat memperkenalkan perluasan lini, perluasan merek, multi merek, dan merek baru (Thamrin dan Francis, 2016:162)

\section{Pengembangan Hipotesis}

Peserta kegiatan pengabdian mampu memproduksi dan merumusakan merek produk sabun mandi dan cuci cair serta merancang brandingnya secara efisien

\section{METODE PENGABDIAN}

\section{Pendekatan Pengabdian}

Kegiatan pengabdian masyarakat mengacu pada pendekatan pemberdayaan masyarakat secara partisipatif.Pendekatan ini menekankan pada upaya peningkatan kualitas manusia agar dapat meningkatkan partisipasi secara nyata dalam berbagai aktifitas kehidupan untuk mendorong terciptanya kegiatan produktif yang bernilai tinggi.

Rancangan Kegiatan

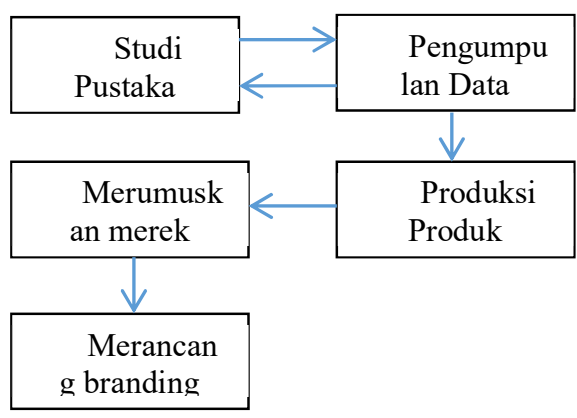

Gambar 3.Rancangan Kegiatan

\section{Ruang Lingkup atau Objek}

Ruang lingkup atau objek kegiatan pengabdian masyarakat meliputi: produksi produk, perumusan merek dan branding

\section{Bahan dan Alat Utama}

Bahan-bahan yang dibutuhkan yaitu Minyak atau lemak, $\mathrm{NaOH} / \mathrm{KOH}$, Air, Essential fragrance oils, Pewarna, Zat adiptif.

Adapun alat-alat yang dubutuhkan yaitu: masker, kacamata, sarung tangan, botol plastic, timbangan dapur, kantong plastic kecil, sebdok stainless steel, wadah dari gelas, wadah dari plastic, kain, plastic tipis, cetakan, kompor, dan blender.

\section{Tempat Pengabdian}

Kegiatan pengabdian dengan tema Pemberdayaan Usaha Masyarakat Melalui Branding Produk dilaksanakan di Kelurahan Sidomulyo timur, Kecamatan Marpoyan Damai.

\section{Teknik Pengumpulan Data}

Teknik pengumpulan data yang dipergunakan dalam penelitian ini adalah studi dokumentasi.Studi dokumentasi adalah teknik pengumpulan data dengan mencari data yang ada dalam dokumen terkait, buku, internet, atau jurnal yang berhubungan dengan pengabdian.

\section{Definisi Operasional}

1. Produk adalahapapun yang bisa ditawarkan ke sebuah pasar dan bisa memuaskan sebuah keinginan atau kebutuhan

2. Brand/Merek adalah nama, istilah, tanda, simbol atau rancangan atau kombinasi dari hal-hal tersebut

3. Branding adalahupaya menjalin keakraban dengan masyarakat 
ISSN : 2550-0198

untuk melahirkan kesuksesan di pasar,

\section{Teknik Analisis}

Untuk menghasilkan produk, merek dan branding yang kompetitif digunakan SWOT sebagai teknik analisis.

Analisis SWOT adalah proses identifikasi berbagai faktor secara sistematis guna menentukan rumusan yang tepat dan melakukan strategi perusahaan yang terbaik. Analisis ini berdasarkan pada logika yang dapat memaksimalkan kekuatan (Strengths) dan peluang (Opportunities), namun secara bersamaan dapat meminimalkan kelemahan (Weaknesses) dan ancaman (Threats).

\section{HASIL DAN PEMBAHASAN}

Merek (brand) dalam lingkup pasar yang kecil memiliki peluang besar mencuri market share dari merek-merek besar yang ada, dengan kemampuannya dalam melayani pelanggan dengan lebih fleksibel dan cara-cara yang lebih kreatif dibanding perusahaan besar terkenal. Menurut Stibel (1988) dalam Anarnkaporn (2007) menyatakan bahwa melalui penerapan strategi merek yang terencana dengan baik, tidak hanya perusahaan nasional saja tetapi juga perusahaan kecil dan menengah (UKM) dapat memenangkan persaingan. Investasi melalui media menghabiskan banyak dana perusahaan. Miskonsepsi inilah yang mendorong Usaha Kecil dan Menengah (UKM) berpikir bahwa mereka hanya perlu fokus pada produk dan harganya saja. Sementara yang sebenarnya terjadi adalah bahwa merek global terpaksa menginvestasikan begitu banyak dana pada media karena kurangnya kemampuan merekauntuk selalu tersedia secara lokal di setiap tempat. Proses inilah yang membuat pelanggan merasa lebih dekat dengan merek global dibandingkan merekmerek lokal atau merek kecil yang sebenarnya secara fisik lebih dekat dengan mereka (Anarnkaporn, 2007). Padahal perlu dipahami bahwa mengembangkan merek itu tidak hanya dapat dilakukan menggunakan periklanan dan media semata, periklanan hanya sebagian kecil saja dari upaya mengembangkan merek.UKM dapat menggunakan kedekatan fisiknya dengan pelanggan untuk menciptakan pengalaman produk dengan pelanggan.Mereka dapat menekankannya pada kekuatan merek dan kredibilitas mereka dengan pelanggan dan meyakinkan pelanggan bahwa merek mereka merupakan pilihan yang lebih baik. Lebih lanjut menurut Anarnkaporn (2007), Usaha Kecil dan Menengah (UKM) perlu menciptakan merek khusus (distinctive brand) bagi produk mereka dengan tujuan agar dapatditerima secara nasional bahkan di pasar luar negeri. Dengan demikian untuk kepentingan tersebut pengusaha UKM perlu memperhatikan kualitas produknya agar dapat memberikan kepuasan bagi pelanggannya dan membangun kepercayaan terhadap pruduk-produk UKM.

\section{KESIMPULAN}

1. Produk yang dihasilkan berupa sabun cuci dan mandi cair dengan thematic buah-buahan 
ISSN : 2550-0198

2. Merek produk adalah SEEPRazes

3. Branding dilakukan melalui edukasi kepada masyarakat melalui label yang ditempel pada produk. Edukasi berbentuk pengenalan tokohtokoh muslim penemu berbagai jenis sabun, yang salah satunya adalah Razes.

\section{UCAPAN TERIMAKASIH}

Kegiatan pengabdian kepada masyarakat tidak mungkin terlaksana tanpa adanya bantuan dan dukungan dari berbagai pihak.

Oleh karena itu pada kesempatan ini, kami ingin menyampaikan terima kasih yang sebesar-besarnya kepada:

1. Lurah Sidomulyo Timur yang berkenan memberikan izin sekaligus memfasilitasi terselenggaranya kegiatan pengabdian dimaksud.

2. LP2M yang telah memberikan dukungan keuangan dalam penyelenggaraan kegiatan dimaksud

3. Ibu-ibu kelurahan Sidomulyo Timur yang tidak bisa kami sebutkan satu persatu. Tanpa kehadiran mereka kegiatan pengabdian dimaksud tidak mungkin akan terselenggara

4. Mahasiswa-mahasiswi FEB dan FMIPA yang telah bersedia memberikan bantuan teknis dan administratif untuk terselenggaranya kegiatan pengabdian kepada masyarakat dimaksud.

\section{DAFTAR PUSTAKA}

[1] Abdullah, Thamrin dan Francis Tantri, 2016, Manajemen Pemasaran, PT. Raja Grafindo Persada, Jakarta.

[2] Anarnkaporn, Angkana. 2007. Branding as a Competitive Advantage for SMEs. RU International Journal.Vol. 1 No. 1. Pp. 25-36.

[3] Assauri, Sofjan 2015, Manajemen Pemasan, PT. Raja Grafindo Persada, Jakarta.

[4] Buchari Alma. 2011. Manajemen Pemasaran dan Pemasaran jasa, Penerbit Alfabeta, Bandung.

[5] Idris, Kamil. 2008, Membuat Sebuah Merek, Pengantar Merek Untuk Usaha Kecil Menengah, Diterbitkan dan diterjemahkan oleh Kamar Dagang dan Industri Indonesia, Jakarta.

[6] Muslim, Aziz. 2007, Pendekatan Partisipatif Dalam Pemberdayaan Masyarakat, Jurnal Aplikasi Ilmu-ilmu Agama, Vol. VIII, No 2 Desember 2007:89-103 